DOI: https://doi.org/10.31874/2309-1606-2020-26-1-10

УДК $1: 371$

\title{
Богдан Адаменко
}

\section{Викладання філософії як її актуалізація}

Наш час, як і будь-який інший, сповнений різними викликами. В контексті стрімкого розвитку наук та технологій, ми неминуче перебуваємо під їхнім впливом. Технології не лиши полегшують наше життя, а й здатні формувати

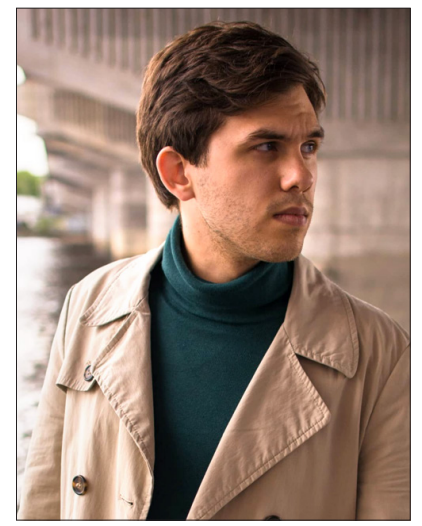
бачення людини в нових реаліях. Вони можуть впливати на вибір та відчуття відповідальності за нього. Таке швидке створення нових ідей та технологій, не дозволяє вчасно та якісно провести оцінку того, який відгук це матиме у нашому майбутньому. Філософи, як люди, що працюють з певними відносно сталими величинами, мають знаходитися на передовій концептуального аналізу та проблематизації тих впливів, на які наражається сучасна людина. Викладання філософії, в такому стані справ, повинне зайняти визначальне місце. Сфера моралі та етичних оцінок, закладає ціннісну базу самоусвідомлення людини та стимулює їі до більш відповідально осмисленого життя. Філософ тут має центральну роль - як той, хто передає дане знання. Використання філософських засобів має в першу чергу починатися з аналізу того, хто їх використовує. Задля чесності перед собою та аудиторією філософ, приступаючи до викладання, повинен починати з себе, з самоусвідомлення, з визначення власних моральних орієнтирів та власної відповідальності. Побоювання викликає ситуація, в якій філософ формує власні думки, розробляє концепції, проводить аналіз та подає аргументацію, не пропрацювавши завчасно із засновками та основами, на яких будує дані міркування. В межах статті було здійснено спробу визначити, хто такий філософ, і яке його місце в сучасному світі. Для розкриття визначення запропонуємо введення термінологічного розрізнення між "філософами мети" та "філософами цілі", яке слугує для нас маркером розгляду філософської діяльності як цілісності, що у своїй основі є сутнісно відповідальною практикою. Завдяки формуванню даних визначень виявлено різницю між філософами та псевдофілософами, надано оцінку важливості перших і негативних наслідків діяльності останніх.

Ключові слова: викладання філософії, самовизначення філософа, відповідальність, відповідальність філософа, завдання сучасного філософа.

Швидкість, на якій зараз несеться людство у створенні нових ідей та технологій, не дозволяє нам робити зупинки для осмислення того шляху, який ми пройшли і яким продовжуємо йти. Філософи, якщо вони дійсно 
претендують на таке високе самовизначення, залишаються єдиними, насправді здатними фіксувати та проблематизувати актуальну реальність як дану. В головах та творах філософів знаходяться ті унікальні засоби, якими вони можуть сформувати критичну та морально-ціннісну базу в інших. Спонукати їх до більш свідомого ставлення до того, чим вони живуть і що створюють. Щоб закласти дійсне бачення, а не нав’язувати ілюзії, філософу варто починати з себе, із власної відповідальності та самовизначення. Викладання філософії, як і будь-яка педагогічна діяльність загалом - це жертовність. Це крок, який зробити легко не вдасться. Варто цілковито усвідомлювати шлях, яким починаєш рух, але перед цим потрібно навчитися орієнтуватися в собі. Неможливо починати спонукати інших до морально-етичних розмислів, якщо сам не визначив свої моральні орієнтири, не сформував особисту цілісність та не побачив виклики свого часу. На жаль, даних передумов дотримуються не всі.

Для того, щоб викладання було чесним і для аудиторії, і для філософа як викладача, окреслимо самовизначення останнього через проведення понятійного розрізнення та наголосимо на відповідальному ставленні філософа до актуального стану справ в інтелектуально-дослідницькому середовищі.

\section{Філософ як викладач}

Задля того щоб краще зрозуміти викладання філософії як засіб формування морально-етичних цінностей, я зроблю відступ і поглиблю тему в річище того, по-перше, хто такий філософ, тобто якою має бути людина, яка приступає до викладання, i, по-друге, спрямую свої розмисли в бік теми філософ і відповідальність. До того, як дати відповідь "як?" потрібно усвідомити “хто?” і з якими основами.

Немає нічого гіршого за людину, яка називає себе філософом, але при цьому не розуміє, яку важливість та навантаженість несе дане самовизначення. Надто багато псевдофілософів, яких я бажав би викрити, та винести цих магів ${ }^{1}$, за межі кола філософів-інтелектуалів. Для такого здійснення, потрібно провести деяке розрізнення, та показати, які сенси я вкладаю у визначення “філософ”. Для мене є філософи цілі та філософи мети. Загалом в нашій мові терміни "ціль" та "мета" мають синонімічний характер, проте моя увага загострюється на їх семантичному розрізненні. Для того щоб його провести звернемося до німецької мови. Ціль, німецький відповідник “Zweck”, вже на рівні буденного

\footnotetext{
${ }^{1}$ Маги чи майстри думки - термін, який вживає Юрген Габермас у своїй доповіді 1981 року “Філософія, як берегиня та інтерпретатор” [Габермас 1998] стосовно тих філософів, які створюють чи створили хибні інтелектуальні основи (парадигми), і яких ми повинні уникати, щоб уберегти Філософію.
} 
слововжитку має інструментальний характер. Початково воно означало гвіздок, який забивався в середину мішені, задля ліпшого прицілювання. Ціль - це про діяльність зараз, наше спрямування в теперішньому. Зауважу, що проводити різницю між поняттями “ціль" та “мета" мене спонукав Макс Горкгаймер [Горкгаймер 2006], який так само, як і Макс Вебер з його “цілераціональною дією”, звертав увагу на інструментальний характер цілі. Горкгаймер проводив дане розрізнення, щоб вказати на хворобу “суб’єктивного розуму”, який більшою мірою покладається на цілі, не переймаючись питаннями їх розумності. Поняття “мети” він використовує стосовно ідей вищого порядку, які спрямовуються у майбутнє, у визначення проблеми людського призначення та шляхів досягнення найвищих цілей. Його розрізнення між “суб”єктивним розумом” та “об'єктивним розумом", відповідно також між “ціллю” та “метою”, було спрямоване на те, щоб показати, як розум ідеологізується та як це призводить до культурного занепаду. Згадуючи Макса Горкгаймера, відразу зазначу, що запропоновані мною терміни та розрізнення не слугують відсилкою до його ідей. Зрештою, ми з ним тут працюємо не на одному проблемному полі, в нас різні завдання та не однакові передумови. Позицію Горкгаймера як філософа я шаную щонайменше тому, що саме його ідеї та візії заклали в мене бачення різниці між “ціллю” та “метою”, що й послугувало кроком до моїх інтуїцій стосовно філософів цілі та філософів мети. Тож повертаюся до власного розрізнення.

Поняття “цілі" я вживаю, у відношенні до діяльності, яка спрямована на точкове розв’язання проблем чи завдань, інколи це навіть про задоволення надто власних інтелектуальних потреб, при цьому в кожному 3 випадків не відбувається повне звернення до загальнозначущості. "Мета" - це завжди про щось більше, про відповідальність перед людством та Буттям загалом. Філософи цілі, це ближче до визначення філософії як професії. Професії як викладання думок інших філософів, маючи при цьому власні думки спонукати інших до Буття, лиш побіжно працюючи над його збереженням. Найважливіше тут у спонуканні інших, і тому це не лиш просто про історію філософії, але й про її збереження. Філософи мети, це вихідці чи учні філософів-цілі. Вони актуалізують, як про це пише Габріель Марсель [Марсель 2001], а я інтерпретую та вписую в даний контекст, в собі вчення різних філософів, в середовищі яких вони мислять себе, але не уподібнюючись іншим, вони проходять власне становлення, задля усвідомлення тривоги та відповідальності за “людськість", та цілісне людське Буття. Філософи цілі та філософи мети, пройшли шлях від академічного навчання, яке я вважаю тут обов'язковим, до власного інтелектуального становлення, проте відповідально порізному ставлять собі завдання та реалізують власний потенціал. “Ставлять собі завдання" - бо філософ завжди має бути незалежним, 
але включеним в актуальний контекст свого часу. "Відповідально порізному” - але в будь-якому разі відповідально, бо, розгортаючи власні думки, концепції, аргументи, але не відчуваючи й не усвідомлюючи відповідальності за них, та їхні впливи на життя, філософ уподібнюється до псевдофілософа, й хоча можливо для себе він сприймається як перше, все одно несе деструкцію та розлад у наше життя, і створює перешкоди, які інші мають весь час долати та прибирати уламки хибних ідей.

\section{Цілі та засоби викладання філософії}

Сучасний світ наповнений уламками різних ідей. Ідей, які є незавершеними, бо в постійній гонитві за новизною, “батьки” ідей не встигають оцінювати власні творіння та лишаючи їх, переходять до створення нових, які на жаль нерідко набувають характеру покручів, без оцінки ризиків та наслідків, що можуть спричинити їхні “діти” у відношенні до людських дітей. Ми починаємо жити у фантастичних романах минулого, які стають нашим зараз. Наука та технології, окрім мінливого “добра”, принесли людям невизначеність, що з цим “добром” робити й куди воно нас може привести. Проблема сучасних наук, на мою думку, у відсутності відповідальності у науковців, які захопилися власною величчю, та несуться з небаченою швидкістю, створюючи щось, не встигаючи пояснити навіщо, і не розуміючи, який це вплив має на людину та Буття.

Люди не встигають. Наука та технології вже не можуть зупинитися в русі вперед, тому і люди не встигають робити зупинки, фіксувати та осмислювати. Ось тут і має з'явитися сучасний філософ. Звісно, він може перебувати в іншому місці, та турбуватися про інші проблеми, залишаючись філософом цілі, та коли мова йде про долю людства, філософ мети не має морального права не з'явитися. Філософ має перебувати у постійному контакті з тими речами, що формують сучасне бачення людини та її власне сприйняття себе. Звісно, політичне життя - така сама важлива річ, яка має однаково важливе значення, як і наука, проте знання, які я маю про вплив політики на самосприйняття людини, я вважаю ще не до кінця сформованими, тому в даній роботі, я зупиняюся лише на технологіях та науці.

Філософ має відчувати свій час і політичні процеси, будучи незмінно пильним, щоб побачити всі можливі деструктивні наслідки вчинків політичних діячів, у відношенні до суспільства, громадян та людства в цілому. В цьому я погоджуюся з Жаком Марітеном [Марітен 2001], який пише, що філософи мають формувати здорову політичну філософію та повинні відкрито висловлювати свої думки та погляди, відстоювати істину, звісно не уникаючи відповідальності. Важливо, щоб філософ залишався тут незалежним, й не був пристосуванцем в політичній системі, й не ставав ідеологом, що неминуче веде до деструктивної псевдофілософії. 


\section{Відповідальність бути філософом}

Філософ відповідальний за трансформацію відповідальності інших людей, які так само, як і сам філософ, перебувають під впливом технологій. Про які технології йдеться? Доволі непогано дану проблему окреслив Джуліан Фрідленд у статті “Штучний інтелект може допомогти нам жити більш свідомо" [Friedland 2019]. Не зважаючи на оптимістичний заголовок, все поки що складається доволі скрутно. Сподіваюся, це допоки до аналізу та оцінки даної проблеми не вдалися філософи мети. В чому ж головна проблема? Застосунки, які встановлені на наших смартфонах чи комп’ютерах, все частіше розробляються на основі технологій машинного навчання. По ходу того, як ми віддаємо Ш багато задач на аутсорс, ми стаємо більш пасивними, менш рефлективними та менш відповідальними за результат.

Найпростіші приклади. Нам потрібно кудись піти, ми відкриваємо карти, і програма будує нам маршрут. Один маршрут. Можливо, цей маршрут і $є$ оптимальним, та це вже не ми вибираємо шлях, яким іти. Так, це усуває фактор стресу, нам не потрібно комунікувати з іншими людьми та запитувати дорогу. Начебто нічого страшного, та це призводить до декваліфікації та погіршення орієнтації в просторі. Проте, навчаючись орієнтуватися в новому некомфортному середовищі, налагоджувати в ньому взаємодії, ми отримуємо контроль, можливо й побічний, та все ж над власною свідомістю.

Другий приклад - це рекомендаційні системи підбору фільмів. Ш підбирає нам релевантні фільми, засновані на наших уподобаннях. Ми не витрачаємо часу на таку рутинну справу, але це погіршує наше "інтелектуальне тертя” та відповідальність за вибір. Додам, що всі застосунки розробляються для того, щоб утримувати нашу увагу та направляються на те, щоб задіювати наш автономний розум, а не рефлективний, як це розрізнює Деніел Канеман. Людина техніки стає менш критичною, легше піддається впливам, та найгірше - “оштучнюючи” себе, нівелює поняття відповідальності.

Може виникнути питання, а яка ж тут роль філософа, і як це взагалі стосується його відповідальності. Філософи тут мають справу з конкретною життєвою ситуацією, яка буде тривати, бо механізми впливу на людину, передусім - через техніку, постійно удосконалюються. Філософи мають бути залученими до окреслення людини в такій новій технологічній реальності, мають закласти основи етики створення нових комп'ютерних програм, бо в інакшому випадку, ми прокинемося у світі, де людина втратить свою “людськість”. Відповідальність філософа постає у збереженні людини, її ідентичності, щоб це не стало "самогубством в масштабах роду людського" [Марсель 2001: 263]. 
Можливо, мої приклади з техніки не були достатньо влучними, просто в даній роботі я не хотів бути надто радикальним і лиш прагнув показати, що навіть в буденному житті, щодня ми маємо справу з речами, які неявно формують наше ставлення до себе, наші інтелектуальні здатності та відчуття світу. Не явно, але в перспективі невпинного розвитку подібних технологій, якщо дана проблематика не втрапить в коло інтересів філософів, може відбутися хибне пристосування до такої реальності. Чи зможуть в ній з'явиться нові критичні філософи - для мене особисто залишається відкритим питанням. Філософи відповідальні за прийдешні покоління філософів.

\section{Висновок}

В даній роботі було проведено термінологічне розрізнення між “філософами цілі” та “філософами мети”, нагадаю його основні ідеї.

Філософи цілі - це ті, хто вже подолали довгий шлях академічного вивчення філософії. Це вже однозначно не школярський рівень навчання та осягнення філософії, а усвідомлено відповідальна робота з філософським інструментарієм. Філософи цілі чітко знають засновки, на яких будуть свої міркування, а також пройшли шляхом самовизначення. Проте, межі їх відповідальності простягаються лиш на збереження ідей минулого та роботі в теперішньому. Важливість філософів цілі - в закладанні бази для себе і для інших. “Для інших" - я тут вживаю в розумінні педагогічної діяльності, яка є значущою та осмисленою. “Для себе” - бо вони своєю роботою роблять можливим власний перехід до філософів мети.

Цілі покладають нам основу для мети. Може бути ціль без мети, але не існує мети без цілі, без основи. Філософи мети працюють з ідеєю майбутнього, з детальною оцінкою теперішнього, його викликів, проблем, але важливе тут саме відчуття відповідальності за майбутнє. Від філософів цілі здійснюється поступ до філософів мети. Для мене дане розрізнення знаходиться в осерді значення “Філософ”. Це два рівні постановки завдань, при цьому кожен з них відповідальний та значущий у своїй діяльності. Це не означає, що філософи мети не можуть займатися викладанням, а філософи цілі не здатні перейти від викладання далі. Безперечно, важлива і перша частина терміну, яка слугує маркером того, що людина вже відповідально здійснила вибір у своєму житті. Вибір, який означає, що процес самовизначення відбувся і більше немає місця релятивізму. В цьому полягає чесність філософа і чесність викладача, і саме в цьому їхня принципова різниця з псевдофілософами.

Чому мені важливо проводити розрізнення. Пишучи про філософів цілі та філософів мети, я намагався окреслити стратегію інтелектуального розвитку. Я прагнув показати, до якого рівня може прийти той, хто 
вибрав шлях вивчення філософії. В контексті навчання, ми не завжди задумуємося, що очікуватиме нас в майбутньому, і яких зусиль це буде вартувати. Для того, щоб навчання не ставало доцільністю без цілі, і щоб спонукати до усвідомленості власного філософського становлення, я й подав дане розрізнення. Це моє перше прагнення. Друге полягає в тому, щоб викладачі філософії були співмірними до філософів цілі. Третє, це вже не прагнення, а пересторога перед викликами часу, щоб в інтелектуальному середовищі з'являлося більше філософів, яких я позначаю як філософів мети. Філософів, які б більше вчували нові виклики, котрі з'являються перед людством.

Можливо, не очевидно, але технології здатні послаблювати наше "інтелектуальне тертя" та відчуття відповідальності. Але це лиш ще один виклик, який показує, що філософи таки неминуче включені у їхнє сучасне. I кожне сучасне сповнене все новими викликами для людства, і в кожному теперішньому, філософи, якщо вони справжні філософи, мають оберігати людей від них самих, дивитися в майбутнє і бачити можливі проблеми та їх вирішення. Відчувати власну недосконалість та постійно перебувати у власному розвитку, разом з часом, в якому вони живуть. Філософи мають робити зупинки, фіксувати здобутки інших сфер, піддавати їх критичному аналізу, інтерпретувати на основі власних думок, зважаючи на мудрість ідей, що вже були дані нам в минулому. Лише відчуваючи відповідальність за майбутнє, тривогу за теперішнє та повагу та критичну оцінку минулого, філософи мають постати перед викликами сучасного суспільства.

\section{Посилання:}

Габермас, Ю. (1998). Філософія як берегиня та тлумач /пер. з нім. Генеза: Філософія, історія, політологія, 6-7 (1-2), 64-74.

Горкгаймер, М. (2006). Критика інструментального розуму /пер. з нім. М.Култаєвої. Київ: ППС-2002.

Маритен, Ж. (2001). Философ во граде. Путь в философию. Антология. Москва: ПЕР СЭ, 274-280.

Марсель, Г. (2001). В защиту трагической мудрости. Путь в философию. Антология. Москва: ПЕР СЭ, 243-269.

Friedland, J. (2019). AI can help us live more deliberately. MIT Sloan Management Review, $60(4)$.

\section{Referenses:}

Friedland, J. (2019). AI can help us live more deliberately. In MIT Sloan Management Review, 60 (4).

Habermas, J. (1998). The philosophy as a placeholder and interpreter. In Heneza: Filosofiya, istoriya, politolohiya, 6-7(1-2), 64-74 [in Ukrainian].

Horkheimer, M. (2006). The Critique of Instrumental Reason. Kyiv: PPS-2002 [in Ukrainian]. 
Marcel, G. (2001). Tragic Wisdom and Beyond. In Path to philosophy. Anthology. Moscow: PER SE, 243-269. [in Russian].

Maritain, J. (2001). A philosopher in the city. In Path to philosophy. Anthology. Moscow: PER SE, 274-280. [in Russian].

\section{Богдан Адаменко. Преподавание философии как ее актуализация}

Наше время, как и любой другое, наполнено различными вызовами. В контексте стремительного развития наук и технологий, мы неизбежно находимся под их влиянием. Технологии не только облегчают нашу жизнь, но и способны формировать видение человеком самого себя в новых реалиях. Они могут влиять на выбор и чувство ответственности за него. Стремительное создание новых идей и технологий, не позволяет вовремя и качественно проводить оценки того, какой отклик это будет иметь в нашем будущем. Философы как те, кто работает с определенными относительно постоянными величинами, должны находиться на передовой концептуального анализа и проблематизации тех воздействий, которым подвергается современный человек. Преподавание философии, при таком положении дел, должно занять определяющее место. Сфера морали и этических оценок, закладывает ценностную базу самоосознания человека и стимулирует его к более ответственно осмысленной жизни. Философ здесь играет центральную роль - как тот, кто передает данное знание. Использование философских средств должно в первую очередь начинаться с анализа того, кто их использует. Чтобы быть честным перед собой и аудиторией, философ, приступая к преподаванию, должен начинать с себя, с самоосознания, с определения собственных моральных ориентиров и собственной ответственности. Опасения вызывает ситуация, в которой философ формирует собственные мысли, разрабатывает концепции, проводит анализ и подает аргументацию, не проработав заранее предпосылки и основания, на которых строит свои размышления. В рамках статьи осуществлена попытка определить, кто такой “Философ” и каково его место в современном мире. Для раскрытия определения предложено ввести терминологическое различие между “философами цели” и “философами видения целей”, что послужило маркером рассмотрения философской деятельности как целостности, которая в своей основе является сущностно ответственной практикой. Благодаря формированию таких определений достигнуто различение между философами и псевдофилософами, сформирована оценка важности первых и негативных последствий деятельности последних.

Ключевые слова: преподавания философии, самоопределение философа, ответственность, ответственность философа, задачи современного философа

\section{Bohdan Adamenko. Lecturing Philosophy as its Actualization}

The present times are full of various challenges, as it always used to be. Having in mind the rapid development of science and technology, we inevitably find 
ourselves under their influence. Thus, technology not only makes our life easier, but is also capable of shaping human perception in new obstacles. It can influence our choices and responsibility beyond them. Such a dynamic rate of producing new ideas and technology does not allow a proper and forehanded evaluation of their response in our near future. Since philosophers work with relatively constant terms, they have to be in the avant-gardé of a conceptual analysis and problem-shaping of the challenges facing modern people. In such circumstances, lecturing philosophy should hold a prominent position. The sphere of morals and ethical evaluations forms value basis for human self-cognition and performs as a stimulus to a more responsibly deliberated life. In this situation, a philosopher finds himself in a crucial role as a person, who provides this knowledge. The use of philosophical means has to start with the analysis of those, who are in charge of their usage. In order to remain frank with the audience and himself, a philosopher should start lecturing from himself, his self-cognition, as well as from a clear deliberation of his personal moral guidelines and personal responsibility. The situation, in which a philosopher shapes his personal ideas, formulates concepts, analyses, and provides arguments without proper elaboration of their premises and basic principles, raises concerns. Within the scope of this article we attempt to designate the term "philosopher" and philosopher's position in the modern world. In order to articulate this term properly, we suggest a distinction in terminology between "philosophers of aim" and "philosophers of purpose", which serves as a marker to estimate philosophic activities in their full scope. In my opinion, any philosophic activities, in their basis, perform as a practice of essential responsibility. The abovementioned definitions provide us with an ability to notice a distinction between philosophers and pseudo-philosophers, as well to evaluate the importance of the ones and the perniciousness of the others.

Keywords: lecturing philosophy, self-determination of philosopher, responsibility, responsibility of the philosopher, task of modern philosopher

Адаменко Богдан Володимирович, студент філософського факультету Київського національного університету імені Тараса Шевченка.

orcid.org/0000-0002-9909-7580

063-711-47-72

E-mail: bohdanadamenko@gmail.com

Adamenko Bohdan Volodymyrovych, undergraduate student, Faculty of Philosophy, Taras Shevchenko National University of Kyiv (Ukraine).

orcid.org/0000-0002-9909-7580

E-mail: bohdanadamenko@gmail.com 